Dajana Ercegovac ${ }^{1}$

Novi Sad School of Business

Emilija Beker Pucar ${ }^{2}$

University of Novi Sad, Faculty of Economics in Subotica
ORIGINAL SCIENTIFIC ARTICLE

DOI: 10.5937/ekonomika2104011E

Received: May, 11. 2021.

Accepted: August, 02. 2021.

\title{
FDI INFLOWS IN SELECTED EMERGING EUROPEAN ECONOMIES WITH REFLECTIONS ON ECONOMIC GROWTH
}

\begin{abstract}
The objective of this paper is to identify the top destination for FDI inflows as well as to analyse related growth progress in selected Emerging European Economies (EEEs) in order to suggest significant implications towards economic policy creators in Western Balkan countries. The authors conducted descriptive statistical analysis together with correlation analysis in the time period 19972019. The analysis of average FDI inflows includes following country groups: Visegrad States, Baltic States, Western Balkan and eleven new EU member states with regard to the structural break of Global Financial Crisis (GFC). The results suggest that the Visegrad States (particularly Poland) were the top locations for foreign investors in the analysed time period. Having in mind a positive correlation link between significant FDI inflows, especially greenfield FDI inflows and economic growth, we suggest that Western Balkan countries should implement adequate measures to attract greater greenfield FDI inflows in order to stimulate real convergence towards developed European economies. Therefore, recommendations are directed towards economic policy of less developed countries of Western Balkan that need to continue to improve the quality of public institutions and infrastructure, as well as business environment and implementation of nonfinancial measures of promotional activities, in order to raise attractiveness of national market for foreign investors.
\end{abstract}

Key words: FDI, economic growth, EEEs, Western Balkan.

JEL classification: E22, F21, O19, O24.

\section{ПРИЛИВИ СДИ ОДАБРАНИХ ЕВРОПСКИХ ЕКОНОМИЈА У РАЗВОЈУ И УСПОНУ СА РЕФЛЕКСИЈАМА НА ЕКОНОМСКИ РАСТ}

Апстракт

Циљ рада је идентификаичја најатрактивнијих локаичја за прилив СДИ, као и анализа повезаног економског напретка у изабраним европским

\footnotetext{
${ }^{1}$ ercegovacdajana@gmail.com, ORCID ID 0000-0002-6526-0773,

2 emilijabp@gmail.com, ORCID ID 0000-0002-6369-3225.
} 
економијама у развоју и успону (ЕEE), како би се пружиле значајне импликачије на економску политику земаља Западног Балкана. Аутори користе метод дескриптивне статистичке анализе заједно са корелационом анализом у временском периоду од 1997 до 2019. године. Анализирани су просечни приливи СДИ по групама земаља у узорку: Вишеградским државама, Балтичким државама, Западном Балкану и једанаест нових чланица ЕУ са освртом на структурни лом изазван Светском финансијском кризом (СФК). Резултати указују да су Вишеградске земље (посебно Пољска) биле најатрактивније локаиије страним инвеститорима у анализираном временском периоду. Имајући у виду позитивну корелащиону везу између значајног прилива СДИ, посебно прилива греенфиелд СДИ и економског раста ЕЕЕ, потребно је да земље Западног Балкана примене адекватне мере привлачења греенфиелд СДИ с ичием стимулације реалне конвергенције ка развијеним европским економијама. Стога, препоруке су усмерене у правиуекономске политикемање развијених економија Западног Балкана, где је неопхоно даље унапређење квалитета државних институција и инфраструктуре, као и пословног окружења и примена нефинансијских промотивних мера, ради повећања атрактивности националног тржишта страним инвеститорима.

Кључне речи: СДИ, економски раст, ЕЕЕ, Западни Балкан.

\section{Introduction}

The convergence process of the Emerging European Economies (EEEs) towards developed countries mostly relies at the substantial inflow of FDI. In the previous period there was considerable problem of insufficient level of total investment and domestic capital accumulation that would bust economic development, especially in the Western Balkan countries. In the EEEs the significant share of FDI was directed in financial and service sector that reflected in the faster economic growth. Also, received greenfield investments were the relevant factor that contributed to the rise of employment and economic development.

The considerable part of the received FDI inflows through acquisitions and greenfield investments were directed in the national banking sector, that together with higher government control contributed to a greater efficiency and restructuring of the domestic banking sector (Ercegovac, Vlaović Begović \& Jovin, 2019).

The aim of this paper is to analyse FDI inflows in selected EEEs, along with the analysis of FDI effects on the real economy, as well as the factors that influence the FDI inflows. Key hypothesis of this research is: Host countries with high levels of FDI, especially greenfield FDI inflows, can achieve positive transmission effects and growth of real economy. The purpose of this paper is to offer relevant implications towards economic policy creators in the Western Balkan economies. Economic policy creators try to balance with goals of internal and external equilibrium on which significant effect has adequate level of the FDI inflows, especially greenfield FDI inflows. De Mello (1999) stresses that larger FDI inflows can affect positively on economic growth through capital accumulation and transfer of technology and knowledge. 
Josifidis, Allegret \& Beker Pucar (2013) state that in the period before Global financial crisis (GFC) substantial FDI inflows were enabled through high global liquidity and low lending costs. Relying on significant foreign capital in the combination with growing current account deficit problem initiated higher sensitivity of emerging economies towards external shocks, sudden stop episodes or capital reversals during GFC, with inevitable restrictive adjustments of real economy (Beker Pucar \& Srdić, 2018). Żuk, Polgar, Savelin, Diaz del Hoyo \& Konig (2018) analyse the level of real convergence and economic development of Central, Eastern and South-eastern Europe and they come to the conclusion that new EU states (Poland, Slovakia and Baltic States) have the fastest improvement, while Western Balkan states still have slow and challenging development pace.

\section{Literature review}

On the basis of different research results in the vast literature, it could be summarized that FDI can have a wide range of positive effects on the host economy like increase in financial resources, increase of employment, competitiveness growth, better access on foreign markets, rise in exports, contemporary technology transfer, human capital improvement and, finally, rise in economic growth (Caves, 1974; Romer, 1993; Noorbakhsh, Paloni \& Youssef, 2001; Brooks \& Sumulong, 2003; Durham, 2004; Crespo \& Fontura, 2007; Azizov, 2007). Walkenforst (2004) highlights that multinational companies had a key role in restructuring and transition of Central and Eastern European economies from socialistic regimes to market oriented economic systems. Numerous studies have shown that FDI inflows had positive effect on economic growth (Borensztein, De Gregorio \& Lee, 1998; Li \& Liu, 2005; Pegkas, 2015; Iamsiraroj \& Ulubasoglu, 2015; Iamsiraroj, 2016). According to Gerschewski (2013) the governments of emerging economies strive to attract greater FDI inflows because they expect positive transmission effects concerning the rise of productivity level and modern technology transfer.

Denisia (2010) points out that FDI inflows affects rise in employment, productivity level, competition, technology transfer, better position on international market, rise in exports and foreign currency inflow. Ercegovac \& Živkov (2018) stated that more FDI inflows in the tradable sector and improvement in competitiveness position can contribute to more balanced current account. According to Bayar (2017) greenfield investments bring greater capital accumulation and productivity, while brownfield investments can affect positively the economic growth through knowledge and technology transfer. The authors who also come to the empirical evidence that greenfield FDI had positive effect on the real economy are Wang \& Wong, 2009; Neto, Brandao \& Cerqueira, 2010; Harms \& Meon 2014; Luu, 2016 and Bayar, 2017.

Luu (2016) comes to conclusion that both, greenfield and brownfield FDI, had positive effect on economic growth. According to Kurtishi-Kastrati (2013) FDI inflows can have positive effects on economic growth and balance of payments that depends on FDI motivation. Blomstrom \& Kokko (1997) also conclude that FDI have potential to stimulate economic growth through increase in productivity and greater exports of host country. Also, Dabla-Norris, Honda, Lahreche \& Verdier (2010) state that larger inflow of foreign capital have been received in more developed countries that have greater 
values of GDP per capita. Anghel (2006) comes to conclusion that more open countries, with higher rates of GDP growth and more qualified labour, had larger inflow of FDI. Dogru (2012) underlines that FDI inflow is significantly determined by the quality of government institutions and administrative business procedures.

Dunning (1994) states that foreign investors can be interested in local market, low cost of domestic resources, efficient production through specialization and strategic assets. Dunning (1992) underlines that government and tax policy, but also business environment, significantly determines the attractiveness of host country as an investment location. Kinoshita \& Campos (2002) claim that motives of foreign investors can be also natural resources, large and growing market, low transport costs, geographical distance and efficient production process. Brakman, Garretsen \& Van Marrewijk (2006) stated that greatest part of FDI was realized through mergers and acquisitions. Mergers and acquisitions are mainly motivated with market volume, decrease of competition and cost reduction. According to UNCTAD (WIR, 2002) factors that have influence foreign investors choice concerning investment location are government policy, economic determinants of local market and business incentives. Government policy includes economic and political stability, regulation for entrance and business of multinational corporations, tax policy, international agreements, trade policy, industrial policy and regional policy. Also, government policy and taxes besides their impact on received FDI inflows have a strong impact on economic growth. Empirical findings of Kalaš, Mirović \& Andrašić (2020) confirm the positive and statistically significant effect of revenues of value added tax and excises on economic growth in the long-run.

Economic determinants of FDI inflows include market volume, consumer preferences, factor costs, labour qualification, modern technology, production capacity, infrastructure, business environment and human capital. Business incentives include promotional activities in process of building positive image of country, financial and nonfinancial incentives for investors, protection of property rights and additional services with administrative procedures (UNCTAD, WIR, 2002).

Wells \& Wint (2000) highlight that promotional program and investor incentives are relevant factors in attracting multinational companies that search the most favourable location for production fragmentation and further export on regional and global market. On the other hand, multinational companies interested in local market pay attention on the business environment and regulation and don't need intense investment incentives. Ruane (2008) points out that financial incentive for foreign investors can have more negative effects because of, so called, "price wars".

In that sense, Ginevičius \& Simelyte (2011) states that fiscal and financial incentive measures can have only short term positive effects in attracting FDI, because multinational companies interested in economic incentives have tendency to transfer capital and escape to more favourable location with predictive government policy. Jovanović, Damnjanović \& Mirović (2016) also find that social stability, reliable infrastructure, competitive local suppliers and highly educated and productive labour have more effect in attracting FDI, while direct subsidies and tax relive aren't efficient ways in attracting foreign investors.

Shukurov, Maitah \& Smutka (2016) states that investor's choice about location depends on the analysis of strengths and weaknesses of host country that further attract certain type of FDI: resource seeking, market seeking or efficiency seeking investments. Dunning (2003) points out that factors that have influence on the choice of investors 
location are permanently changing. In larger emerging economies traditional economic factors like cheap labour, natural resources and market volume are still significant factors, while in advanced industrial economies multinational companies are now looking for knowledge and innovation based capabilities with adequate trade, legal and communication policy and infrastructure. Canton \& Solera (2016) points out that received greenfield FDI inflow in EU countries were influenced by flexible regulation, market volume, labour quality and lower distance between host and home country of investor. Authors conclude that macroeconomic factors, regulations and business environment had the most influence on attraction of foreign investments.

Transition economies of Western Balkan had less FDI inflows compared to the Central European countries because of slow process of reforms, political instability, infrastructure disabilities and inefficient institutions. It is necessary to underline that positive effects and nature of connection between FDI and host economy depends on level of economic development, industry characteristics, financial sector development and business environment of host country, but also from motivation and industry sector of investment.

\section{Research Design and Methodology}

Literature review gives relevant findings about positive effects of substantial foreign capital inflows with regard to the key factors that motivate FDI inflows. The authors analyse FDI inflows because they are the fuel that triggers changes and economic development in less developed and transition economies. The main goal of the paper is to identify the top destination for total and greenfield FDI inflows and analyse the annual GDP growth rates in EEEs in order to suggest useful recommendations for economic policy creators in the Western Balkan economies. Also, previous capital inflows are relevant factor that new investors consider in identification of foreign locations for their production facilities and market expansion strategies.

Research hypothesis is as follows: Host countries with high levels of FDI, particularly greenfield FDI inflows, can achieve positive transmission effects related with real economy, namely stimulation of economic growth. In order to analyse a magnitude of received FDI and greenfield FDI, as well as the level of annual GDP growth rates in selected EEEs, the authors use a method of descriptive statistical analysis with graphical presentation of analysed indicators. Also, authors use the Pearson correlation in order to determine if there is a positive link between the FDI inflows and GDP growth rate in selected EEEs. Methodology used is this paper is comparative analysis, backed up with descriptive statistics and correlation analysis, with the purpose of giving inductive conclusions focused on government policy recommendations for Western Balkan countries.

Research sample are sixteen EEEs i.e. transition economies that become EU members in 2004, 2007 and 2013 with countries of Western Balkan that are in the process of convergence towards the EU. Authors compare received FDI inflows by countries and by next four groups - Visegrad States, Western Balkan, Baltic States and eleven new EU member states. Also, the analysis covers received greenfield FDI by countries and country groups with comparative look at Poland, Western Balkan and Serbia. 
In order to back up the defined hypothesis we analyse the real growth indicator by countries and country groups with graphical presentation for Poland, Western Balkan and Serbia. Key yearly variables are obtained from UNCTAD, FDI/MNE database, WIR2020 and Word Bank Sustainable Development Goals Database. Descriptive analysis of FDI inflows has been performed for the period 1997-2019, but also in regard to the structural break of the GFC (before GFC 1997-2007 and after GFC 2008-2019). Descriptive analysis of greenfield FDI inflows is conducted for the available data in the period 2003-2019. Annual GDP growth rates in the period 1997-2019 are investigated with the focus on average growth rates and volatility level measured with standard deviation. Correlation analysis covers the link between the FDI inflows and GDP growth rate for the period 1997-2019 and the link between the greenfield FDI inflows and GDP growth rate for the period 2003-2019 in selected EEEs.

\section{Research Results and Discussion}

\section{The analysis of FDI inflows in selected EEEs}

On the basis of descriptive analysis of FDI inflows presented in Table 1, we can point out that admission in the EU was relevant factor in the process of attracting foreign investors in the analysed time period. If we look average FDI inflows for total period of time (1997-2019) we see that Poland was the top destination for FDI with average FDI inflows of 10.4 billion USD. Moreover, Poland recorded maximum level of received FDI inflows compared to the total sample after 2004 and admission in the EU. Besides Poland, high level of average FDI inflows was obtained in Czech Republic and Romania. Countries that have received higher level of FDI after admission in the EU were: Hungary, Romania, Bulgaria and Czech Republic. Also, we can point out that Hungary along with the high FDI inflows also had the biggest FDI outflow.

Table 1: Descriptive analysis of FDI inflows in selected EEEs (1997-2019) in millions USD

\begin{tabular}{|l|c|c|c|r|r|r|}
\hline $\begin{array}{c}\text { Emerging } \\
\text { European } \\
\text { Economies }\end{array}$ & $\begin{array}{c}\text { Average FDI } \\
\text { inflows (1997- } \\
\mathbf{2 0 1 9 )}\end{array}$ & $\begin{array}{c}\text { Average FDI } \\
\text { inflows before } \\
\text { GFC (1997- } \\
\mathbf{2 0 0 7 )}\end{array}$ & $\begin{array}{c}\text { Average FDI } \\
\text { inflows after } \\
\text { GFC (2008- } \\
\mathbf{2 0 1 9 )}\end{array}$ & Median & Minimum & Maximum \\
\hline Poland & $10.419,27$ & $8.761,23$ & $11.939,13$ & $12.140,25$ & $2.734,02$ & $19.836,22$ \\
\hline Czech Republic & $5.927,11$ & $5.917,57$ & $5.935,84$ & $5.641,74$ & 465,10 & $11.653,25$ \\
\hline Hungary & $3.620,76$ & $4.126,21$ & $3.157,44$ & $3.936,05$ & $-14.750,64$ & $14.409,22$ \\
\hline Slovak Republic & $2.186,41$ & $2.961,72$ & $1.475,71$ & $2.276,71$ & $-604,08$ & $5.864,88$ \\
\hline Visegrad States & $\mathbf{5 . 5 3 8 , 3 9}$ & $\mathbf{5 . 4 4 1 , 6 8}$ & $\mathbf{5 . 6 2 7 , 0 3}$ & $\mathbf{4 . 8 8 9 , 1 2}$ & $\mathbf{- 1 4 . 7 5 0 , 6 4}$ & $\mathbf{1 9 . 8 3 6 , 2 2}$ \\
\hline Estonia & $1.135,30$ & 972,55 & $1.284,48$ & 928,00 & 12,97 & $3.044,48$ \\
\hline Latvia & 730,18 & 677,14 & 778,81 & 706,19 & 93,88 & $2.323,67$ \\
\hline Lithuania & 778,31 & 796,41 & 761,73 & 700,04 & $-23,32$ & $1.984,38$ \\
\hline Baltic States & $\mathbf{8 8 1 , 2 7}$ & $\mathbf{8 1 5 , 3 7}$ & $\mathbf{9 4 1 , 6 7}$ & $\mathbf{7 2 4 , 9 7}$ & $\mathbf{- 2 3 , 3 2}$ & $\mathbf{3 . 0 4 4 , 4 8}$ \\
\hline Slovenia & 642,80 & 517,76 & 757,43 & 675,46 & $-475,83$ & $1.674,41$ \\
\hline Romania & $4.467,91$ & $3.909,41$ & $4.979,86$ & $3.601,36$ & $1.027,03$ & $13.491,54$ \\
\hline Bulgaria & $2.780,80$ & $3.144,93$ & $2.447,02$ & $1.549,13$ & 646,66 & $12.388,86$ \\
\hline
\end{tabular}




\begin{tabular}{|l|c|c|c|r|r|r|}
\hline Croatia & $1.821,34$ & $1.698,37$ & $1.934,06$ & $1.425,48$ & 267,36 & $5.317,18$ \\
\hline $\begin{array}{l}\mathbf{1 1} \text { new EU } \\
\text { member states }\end{array}$ & $\mathbf{3 . 1 3 7 , 2 9}$ & $\mathbf{3 . 0 4 3 , 9 4}$ & $\mathbf{3 . 2 2 2 , 8 6}$ & $\mathbf{1 . 6 9 7 , 1 9}$ & $\mathbf{- 1 4 . 7 5 0 , 6 4}$ & $\mathbf{1 9 . 8 3 6 , 2 2}$ \\
\hline Albania and & 663,09 & 217,05 & $1.071,96$ & 855,44 & 41,20 & $1.289,69$ \\
\hline $\begin{array}{l}\text { Bosnia } \\
\text { Herzegovina }\end{array}$ & 428,05 & 399,18 & 454,51 & 381,05 & 0,00 & $1.819,24$ \\
\hline Montenegro & 436,00 & 203,98 & 648,68 & 489,81 & 0,00 & $1.527,26$ \\
\hline Serbia & $2.137,15$ & $1.304,45$ & $2.900,46$ & $1.996,14$ & 51,78 & $4.932,25$ \\
\hline North Macedonia & 295,96 & 237,93 & 349,16 & 256,34 & 0,00 & 725,20 \\
\hline Western Balkan & $\mathbf{7 9 2 , 0 5}$ & $\mathbf{4 7 2 , 5 2}$ & $\mathbf{1 . 0 8 4 , 9 5}$ & $\mathbf{4 4 7 , 3 5}$ & $\mathbf{0 , 0 0}$ & $\mathbf{4 . 9 3 2 , 2 5}$ \\
\hline
\end{tabular}

Source: Authors calculation on the basis of yearly data from UNCTAD, WIR2020.

Based on the results of descriptive statistics we can say that the most attractive locations for foreign investors in the analysed sample were Poland, Czech Republic and Romania. If we compare average FDI inflows by country groups we can highlight that Visegrad States received the most of FDI inflows in the analysed sample in whole observed period. Also, Baltic group and Western Balkan countries had the lowest average of FDI inflows (less than 1 billion USD). Within the Baltic group Estonia had the largest average FDI inflows, while in Western Balkan group Serbia has received more average FDI. Maximum level of received FDI inflows in the Baltic group was recorded in Estonia in 2019, however the three times less than average in the case of Poland. In the Western Balkan group maximum level of received FDI inflows was received in Serbia in 2011, still two time less than Polish average.

If we analyse average FDI flows by country groups in two time sub samples (preGFC and post-GFC periods), we can see that new EU member states, as well as Visegrad and Baltic States, had slightly higher average FDI inflows after GFC. The biggest growth of average FDI inflows was recorded in Western Balkan countries that had only 472 million USD before GFC, but after GFC had two times higher level of average FDI inflows (1.1 billion USD). The main reasons for higher FDI inflows in Western Balkan group were higher FDI inflows in Serbia and Albania after transition reforms and macroeconomic stabilization. Serbia had two times higher average FDI inflows after GFC, while Albania had five times bigger average FDI inflows after GFC. Reasons for higher growth rate of average FDI inflows in Albania were very low level of received FDI inflows before GFC and more interest of foreign investors since 2007.

Cvetanović, Despotović \& Milovanović (2018) also analysed FDI inflows in Western Balkan countries (2000-2016) and they come to conclusion that received inflow was insufficient. In order to attract more foreign investors and promote domestic investments it is necessary to continue to improve situation in public institutions and conditions for business activities. Cvetanović, Nedić \& Despotović (2019) stated that Western Balkan countries significantly improved business conditions measured with World Bank Ease of Doing Business Indicators (2006-2017). The North Macedonia especially had a great progress that is aspiring to the rest of the region to conduct further changes and establish more favourable environment for starting a business and attract foreign investors.

If we analyse average FDI inflows by countries in regard to the GFC, we can see that Poland before GFC had 8.8 billion USD, and after GFC had 29\% increase in average FDI inflow. The new EU member countries that after GFC have recorded slight 
rise in average FDI inflows were Romania, Slovenia, Estonia, Latvia and Croatia, while in Czech Republic the average FDI inflows were balanced in the two sub-periods. On the other hand, Hungary, Slovakia, Lithuania and Bulgaria recorded decrease in average FDI inflows after the GFC. Also, Bosnia and Herzegovina and North Macedonia had the lowest average FDI inflows that are less than 500 million USD in the both sub periods.

In the Figure 1 is presented a comparative look at average FDI inflows by country groups in the period 1997-2019. It is evident that since entrance in the EU, the group of new EU member states obtained high level of FDI inflows until the GFC in 2007. Analysing the movement of FDI inflows we can point out that Western Balkan countries before 2005 were far behind the new EU member states with very low capital inflow. After the GFC situation is slowly improving, received FDI inflow was stable but still insufficient in regard to the needed capital incentives. Baltic group of countries has similar pattern of received FDI inflows that is more stable compared to the new EU member states but at a very low level. It is evident that new EU member states and Visegrad group of countries had a greater volatility and sharp drops of received FDI inflows compared to the Baltic States and Western Balkan.

Figure 1: The comparative look at average FDI inflows by country groups

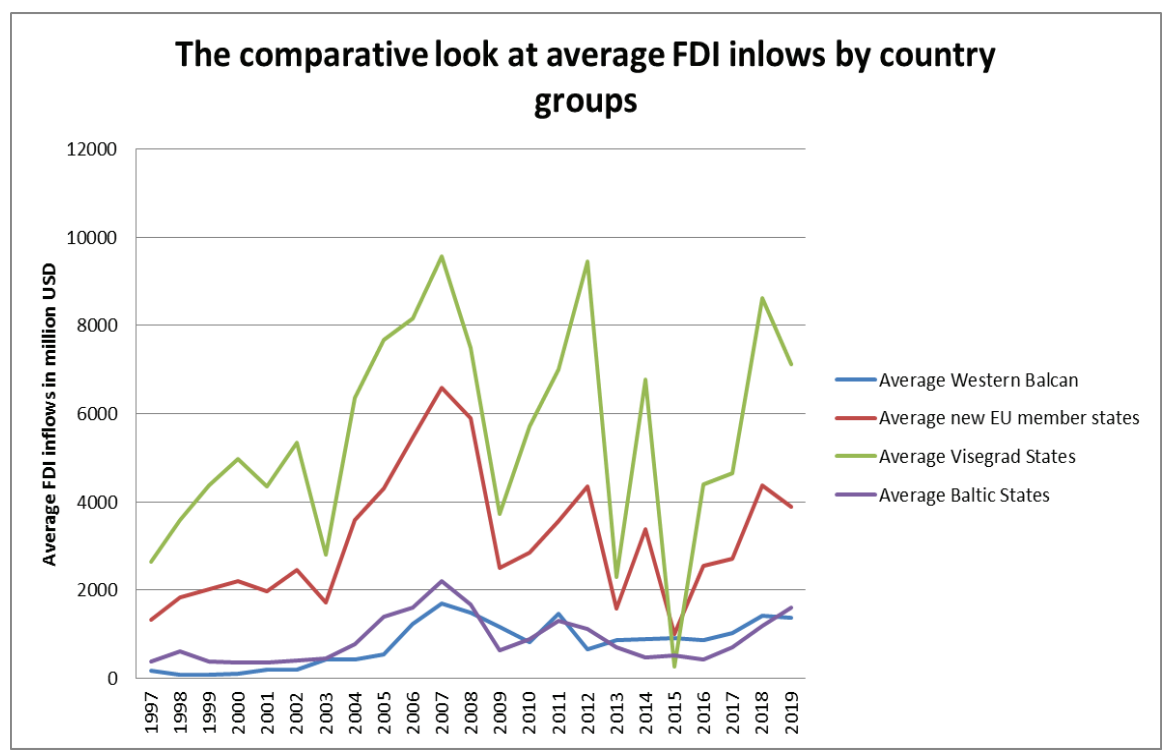

Source: Authors review based on average FDI inflows (https://unctad.org/topic/investment/ investment-statistics-and-trends).

In Visegrad group we can see that EU admission had strong impact on the high growth of FDI inflows that was stopped with the GFC. If we analyse movement of FDI inflows in Visegrad group we can see that there is a greater volatility in the FDI inflows with very high growth rates, but also sharp drops. The source of high volatility of average FDI inflows in the group of new EU member states and Visegrad group could be the capital movements in Hungary that were very unstable with huge capital outflows. 


\section{The analysis of greenfield FDI inflows in selected EEEs}

In Table 2 is presented descriptive analysis of greenfield FDI inflows in EEEs (20032019). It could be pointed out that Poland had huge greenfield FDI inflows with maximum level of 28.3 billion USD in 2008. Average greenfield FDI inflow in Poland was 14 billion USD and is the greatest average volume compared to every other country in analysed sample. The second country by the volume of received average greenfield FDI was Romania that received maximum level of FDI in 2008. If we analyse Visegrad group of countries we can see that Czech Republic, Hungary and Slovakia had significantly less greenfield FDI compared to Poland and had average greenfield FDI inflow about 4-5 billion USD.

If we compare average greenfield FDI inflows by country groups it could be stressed that Baltic States and Western Balkan countries had very low inflow of greenfield FDI. Also, we can highlight that in the analysed sample nine countries have significantly low level of greenfield FDI (Estonia, Latvia, Lithuania, Slovenia, Croatia, Albania, Bosnia and Herzegovina, Montenegro and North Macedonia) with average level of greenfield FDI inflows less than 1.5 billion USD. If we look at average greenfield inflow in Western Balkan group we can highlight that Serbia has the greatest level of received greenfield FDI with average of 3.4 billion USD and maximum level of 6.7 billion USD in 2018. It is interesting to compare the maximum level of received greenfield FDI in Serbia that is proximal to minimum level of received greenfield FDI in Poland. This implies that Western Balkan countries must attract more foreign investments, especially greenfield projects. Less developed countries, like Western Balkan group, need to attract greater volume of FDI as well as to promote rise in domestic savings, in order to achieve the greater level of economic development.

Table 2: Descriptive analysis of greenfield FDI inflows in selected EEEs (2003-2019) in millions USD

\begin{tabular}{|l|c|r|r|r|}
\hline \multicolumn{1}{|c|}{$\begin{array}{c}\text { Emerging European } \\
\text { Economies }\end{array}$} & $\begin{array}{c}\text { Average } \\
\text { greenfield } \\
\text { FDI inflows }\end{array}$ & Median & Minimum & Maximum \\
\hline Poland & $13.951,36$ & $13.199,13$ & $6.238,53$ & $28.257,06$ \\
\hline Czech Republic & $4.159,20$ & $3.912,79$ & $2.115,38$ & $6.886,16$ \\
\hline Hungary & $5.423,39$ & $4.894,23$ & $2.220,14$ & $9.480,33$ \\
\hline Slovak Republic & $3.717,56$ & $3.054,80$ & $1.198,19$ & $9.259,54$ \\
\hline Visegrad States & $\mathbf{6 . 8 1 2 , 8 8}$ & $\mathbf{4 . 9 0 5 , 1 4}$ & $\mathbf{1 . 1 9 8 , 1 9}$ & $\mathbf{2 8 . 2 5 7 , 0 6}$ \\
\hline Estonia & 786,13 & 800,89 & 176,20 & $1.701,53$ \\
\hline Latvia & $1.051,77$ & 694,67 & 249,55 & $3.139,10$ \\
\hline Lithuania & $1.109,60$ & $1.092,69$ & 526,44 & $2.034,39$ \\
\hline Baltic States & $\mathbf{9 8 2 , 5 0}$ & $\mathbf{8 0 8 , 0 1}$ & $\mathbf{1 7 6 , 2 0}$ & $\mathbf{3 . 1 3 9 , 1 0}$ \\
\hline Slovenia & 526,08 & 447,54 & 136,71 & $1.851,30$ \\
\hline Romania & $10.024,87$ & $7.494,29$ & $3.510,10$ & $29.113,14$ \\
\hline Bulgaria & $4.261,71$ & $3.220,56$ & $1.080,88$ & $15.418,73$ \\
\hline Croatia & $1.185,91$ & 898,69 & 381,49 & $2.849,44$ \\
\hline 11 new EU member states & $\mathbf{4 . 1 9 9 , 7 8}$ & $\mathbf{2 . 2 2 0 , 1 4}$ & $\mathbf{1 3 6 , 7 1}$ & $\mathbf{2 9 . 1 1 3 , 1 4}$ \\
\hline Albania & 648,58 & 182,90 & 12,03 & $4.457,82$ \\
\hline Bosnia and Herzegovina & $1.100,20$ & 895,50 & 290,75 & $3.140,49$ \\
\hline
\end{tabular}




\begin{tabular}{|l|c|r|r|r|}
\hline Montenegro & 500,83 & 387,80 & 0,00 & $1.987,95$ \\
\hline Serbia & $3.375,93$ & $3.709,74$ & 918,15 & $6.699,13$ \\
\hline North Macedonia & 693,21 & 534,16 & 110,53 & $2.661,53$ \\
\hline Western Balkan & $\mathbf{1 . 2 6 3 , 7 5}$ & $\mathbf{6 5 9 , 6 2}$ & $\mathbf{0 , 0 0}$ & $\mathbf{6 . 6 9 9 , 1 3}$ \\
\hline
\end{tabular}

Source: Authors calculation on the basis of yearly data from UNCTAD, WIR2020.

In the Figure 2 is presented a comparative look at average greenfield FDI inflows in Poland, Western Balkan and Serbia in the period 2003-2019. It is evident that the EU admission had influenced the huge greenfield FDI inflows in Poland until the GFC in 2007. After the GFC Poland obtained a lower level of FDI with significant downward trend until the 2014 when greenfield FDI inflows started a trend of recovery and growth. Also, process of recovery from consequences of the GFC influenced on the lower rates of global capital investments of MNE, but Poland compared to the other less developed emerging countries (Western Balkan) still have far greater FDI inflows. If we compare Serbia to the Poland as an example of positive transmission effects of FDI inflows, we can see that until the GFC difference was enormous, but since the GFC inflow of greenfield FDI in Serbia was more closer until the 2015 when difference become again vast.

Figure 2: The comparative look at average greenfield FDI inflows in Poland, Western Balkan and Serbia

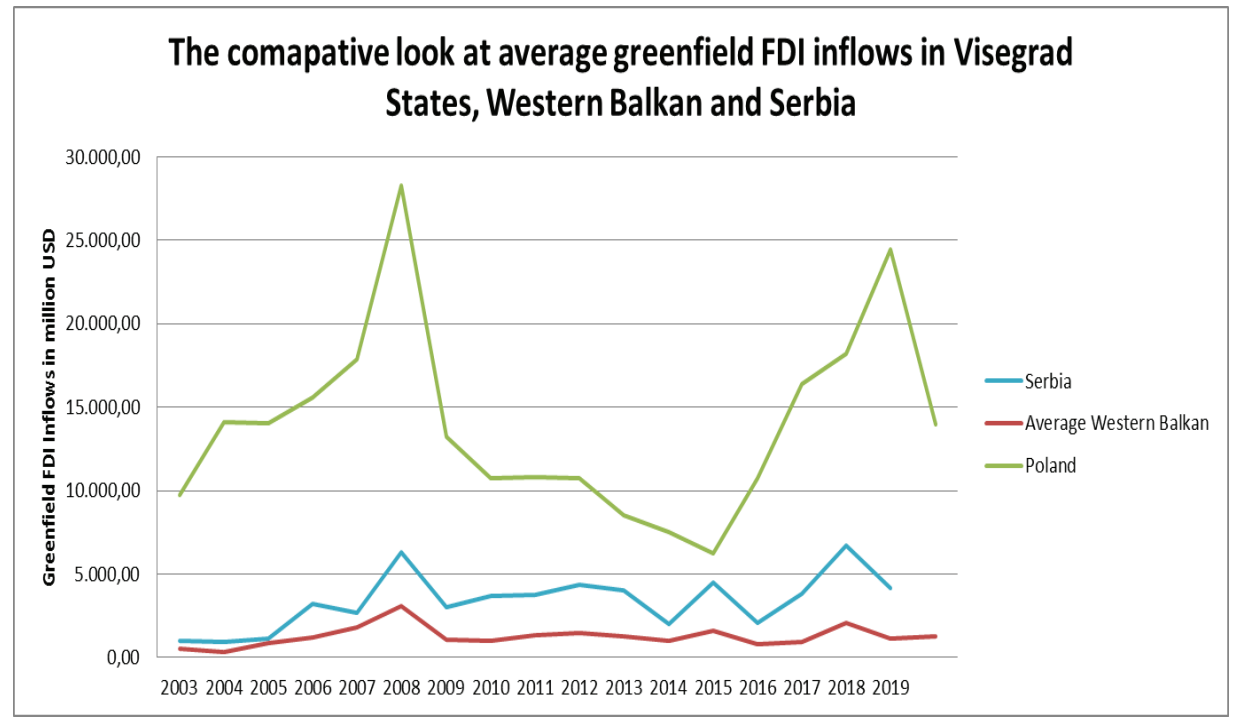

Source: Authors review based on average greenfield FDI inflows (https://unctad.org/topic/ investment/investment-statistics-and-trends).

When we compare greenfield FDI inflows in Serbia and average of Western Balkan group of countries it is evident that Serbia received more foreign capital but still insufficient. Based on this analysis it is clear that Western Balkan countries must place more effort in process of attracting foreign investors. 


\section{The analysis of GDP growth rates in selected EEEs}

In order to give substance to the hypothesis that countries with high level of total and greenfield FDI can have positive transmission effects on growth of real economy, authors present results of descriptive analysis of the annual GDP growth rates in selected EEEs obtained from the World Bank database (1997-2019). On the basis of descriptive analysis in Table 2 and 3 we can again highlight that Poland had the highest total and greenfield FDI inflows in the analysed sample of selected EEEs (1997-2019). Furthermore, in a Table 3 authors give a closer look at the annual rate of GDP growth with descriptive statistics by countries and country groups.

Descriptive analysis reveals that Polish average rate of GDP growth was very high at $4 \%$ with standard deviation of $1.53 \%$. It is interesting that in the analysed period minimum level of GDP growth rate was $1.3 \%$ in 2001 and that Poland does not have negative growth rates not even in crisis period of the GFC. On the other hand, the rest of the EU countries in the sample recorded very low minimum growth rates in crisis period in range from $-14.8 \%$ to $-3.4 \%$. After EU admission in 2004, Polish growth rates were substantial, about $3-7 \%$. Significant level of GDP growth in Poland and low volatility of annual growth rates suggest that there is trend of substantial real growth that is most likely connected with high volume of received FDI inflows. However, for more specific empirical results concerning the link between FDI inflows and the stimulation of a real convergence, more detailed and specific research should be conducted, based at panel data set for selected groups of EEEs.

Analysing the results of descriptive statistics by country groups presented in Table 3 it can be stressed that Baltic States have a very high average growth rates but with more volatility compared to the rest of analysed sample. Visegrad group of countries have average growth rates in range of $2.5-4 \%$ with a lower standard deviation $1.5-3.1 \%$ that suggest that progress of the real economy was more stable. This is in the line with defined hypothesis that countries with higher level of received FDI inflows can achieve the better results of real convergence towards the core EU countries. Western Balkan countries have average growth rates in range of $2.6-5.5 \%$ with a greater volatility that indicates that progress pace is still unstable and dependent from external conditions. Żuk, Polgar, Savelin, Diaz del Hoyo \& Konig (2018) also concluded that new EU states (Poland, Slovakia and Baltic States) have the fastest improvement of real convergence, while Western Balkan countries still have challenging development path.

Table 3: Descriptive analysis of annual GDP growth rate in selected EEEs (1997-2019)

\begin{tabular}{|l|c|c|r|r|r|}
\hline $\begin{array}{c}\text { Emerging European } \\
\text { Economies }\end{array}$ & Average & $\begin{array}{c}\text { Standard } \\
\text { deviation }\end{array}$ & Median & Minimum & Maximum \\
\hline Poland & 4,01 & 1,53 & 4,15 & 1,25 & 7,04 \\
\hline Czech Republic & 2,51 & 2,64 & 2,68 & $-4,80$ & 6,85 \\
\hline Hungary & 2,73 & 2,63 & 3,90 & $-6,70$ & 5,09 \\
\hline Slovak Republic & 3,73 & 3,14 & 3,90 & $-5,46$ & 10,83 \\
\hline Visegrad States & $\mathbf{3 , 2 5}$ & $\mathbf{2 , 6 3}$ & $\mathbf{3 , 6 1}$ & $\mathbf{- 6 , 7 0}$ & $\mathbf{1 0 , 8 3}$ \\
\hline Estonia & 4,28 & 5,52 & 4,76 & $-14,43$ & 13,05 \\
\hline Latvia & 4,11 & 5,56 & 4,28 & $-14,24$ & 11,89 \\
\hline
\end{tabular}




\begin{tabular}{|l|l|l|r|r|r|}
\hline Lithuania & 4,25 & 4,97 & 3,93 & $-14,81$ & 11,09 \\
\hline Baltic States & $\mathbf{4 , 2 1}$ & $\mathbf{5 , 3 5}$ & $\mathbf{4 , 3 3}$ & $\mathbf{- 1 4 , 8 1}$ & $\mathbf{1 3 , 0 5}$ \\
\hline Slovenia & 2,69 & 3,00 & 3,28 & $-7,55$ & 6,98 \\
\hline Romania & 3,22 & 4,16 & 3,87 & $-5,52$ & 10,43 \\
\hline Bulgaria & 2,36 & 4,95 & 3,81 & $-14,19$ & 7,15 \\
\hline Croatia & 2,11 & 3,13 & 2,94 & $-7,36$ & 6,75 \\
\hline $\mathbf{1 1}$ new EU member states & $\mathbf{3 , 2 7}$ & $\mathbf{4 , 0 4}$ & $\mathbf{3 , 6 7}$ & $\mathbf{- 1 4 , 8 1}$ & $\mathbf{1 3 , 0 5}$ \\
\hline Albania & 4,17 & 4,21 & 4,07 & $-10,92$ & 12,89 \\
\hline Bosnia and Herzegovina & 5,50 & 7,18 & 4,00 & $-3,00$ & 34,39 \\
\hline Montenegro & 2,63 & 3,97 & 3,31 & $-9,40$ & 8,57 \\
\hline Serbia & 3,18 & 3,93 & 4,19 & $-9,42$ & 9,03 \\
\hline North Macedonia & 2,88 & 2,12 & 3,36 & $-3,07$ & 6,47 \\
\hline Western Balkan & $\mathbf{3 , 6 8}$ & $\mathbf{4 , 7 1}$ & $\mathbf{3 , 5 9}$ & $\mathbf{- 1 0 , 9 2}$ & $\mathbf{3 4 , 3 9}$ \\
\hline
\end{tabular}

Source: Authors calculation on the basis of yearly data from the World Bank database.

This research is focused on progress of Western Balkan group of countries in order to shed more light on research problem and suggest significant government policy implications. In that sense, in Figure 3 is presented comparison of Western Balkan and Serbia with Poland as a positive example of real progress with high level of foreign investment. Looking at the Figure 3 it is evident that Western Balkan and Serbia have expectedly a more volatile and lower growth rates compared to Poland. In the period 2000-2008 Serbian growth rates were substantial because of the transition process, democratic changes and high level of FDI investments. After the GFC growth pace of Western Balkan was slower, but since 2015 it is again in raising trend.

Figure 3: The comparative look at annual GDP growth rates in Poland, Western Balkan and Serbia

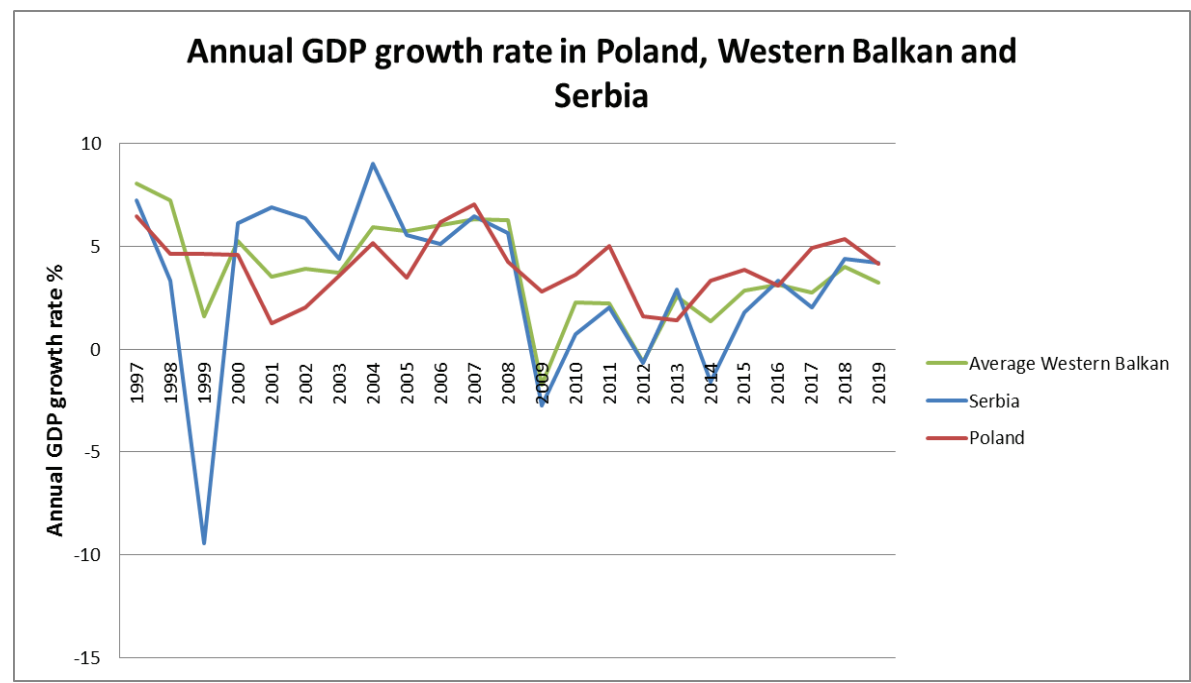

Source: Authors review based on annual GDP growth rates (https://datacatalog. worldbank.org/dataset/sustainable-development-goals). 
In Table 4 is presented the correlation calculation between the FDI inflows (with greenfield FDI inflows) and GDP growth rate in selected EEEs. The Pearson coefficient of correlation between the FDI inflows (in millions USD) and GDP growth rate is calculated by individual countries on the basis of yearly data (1997-2019). The Pearson coefficient of correlation between the greenfield FDI inflows (in millions USD) and GDP growth rate is also calculated by individual countries on the basis of yearly data (20032019). Based on the results we can stress that a strong positive linear link between the FDI inflows and GDP growth is evident in Romania $(0,59)$ and Slovak Republic $(0,54)$, along with a moderately high positive link in Poland $(0,42)$, Slovenia $(0,41)$, Bulgaria $(0,37)$, Lithuania (0,35), Czech Republic and Latvia (0,32). These results back up the assumption that economic growth of the new EU member countries is stimulated with high volumes of received FDI inflows, but also high economic growth has influence on attracting greater FDI inflows.

Table 4: Pearson correlation between FDI inflows and GDP growth in selected EEEs

\begin{tabular}{|l|c|c|}
\hline \multicolumn{1}{|c|}{$\begin{array}{c}\text { Emerging European } \\
\text { Economies }\end{array}$} & $\begin{array}{c}\text { Correlation FDI inflows } \\
\text { \& GDP growth }\end{array}$ & $\begin{array}{c}\text { Correlation Greenfield FDI } \\
\text { inflows \& GDP growth }\end{array}$ \\
\hline Poland & $0,42^{*}$ & $0,43^{*}$ \\
\hline Czech Republic & $0,32^{*}$ & $0,35^{*}$ \\
\hline Hungary & $-0,08$ & 0,09 \\
\hline Slovak Republic & $0,54^{* *}$ & $0,54^{* *}$ \\
\hline Estonia & $-0,15$ & $-0,10$ \\
\hline Latvia & $0,32^{*}$ & 0,25 \\
\hline Lithuania & $0,35^{*}$ & 0,02 \\
\hline Slovenia & $0,41^{*}$ & $0,35^{*}$ \\
\hline Romania & $0,59^{* *}$ & 0,23 \\
\hline Bulgaria & $0,37^{*}$ & $0,45^{*}$ \\
\hline Croatia & $-0,08$ & $-0,30$ \\
\hline Albania & $-0,24$ & $0,60^{* *}$ \\
\hline Bosnia and Herzegovina & $-0,25$ & 0,15 \\
\hline Montenegro & 0,01 & 0,19 \\
\hline Serbia & 0,06 & $-0,15$ \\
\hline North Macedonia & 0,24 & 0,23 \\
\hline $\begin{array}{l}\text { Notes: }{ }^{* *} \text { strong correlation }(\rho>0.5),{ }^{*} \text { moderately high correlation }(\rho>0.3), \text { weak correlation } \\
(\rho<0.3) .\end{array}$ & & \\
\hline
\end{tabular}

Source: Authors calculation on the basis of yearly data from UNCTAD, WIR2020 and World Bank.

The correlation coefficients in Table 4 indicate a strong positive link between the greenfield FDI inflows and GDP growth for Albania $(0,60)$ and Slovak Republic $(0,54)$, along with a moderately high positive link in Bulgaria $(0,45)$, Poland $(0,43)$, Czech Republic and Slovenia $(0,35)$. These findings also back up the hypothesis that high volume of received greenfield FDI inflows is positively linked with high economic growth. 
On the other hand, an inverse weak link between the FDI and GDP growth is recorded in Hungary, Estonia, Croatia, Albania and Bosnia and Herzegovina. Moreover, an inverse link between the greenfield FDI and GDP growth is also present in the analysed sample for the next three countries: Estonia, Serbia and Croatia. A negative correlation indicates that FDI wasn't a stimulating factor as expected in mentioned countries and that some other factors determined the economic growth. Connecting all presented research results in this paper, authors in next section give concluding remarks and recommendations.

\section{Conclusion}

Based on the presented original descriptive analysis of total and greenfield FDI inflows we can point out that admission in the EU was a relevant factor in the process of attracting foreign investors. If we compare average FDI inflows by country groups, it could be highlighted that Visegrad group of economies have received the most FDI inflows in the analysed sample. On the other hand, Western Balkan and Baltic States had the lowest average of total and greenfield FDI inflows. Based on the research results Poland was the top destination for foreign investors with the highest average of total and greenfield FDI inflows in the analysed sample of selected EEEs in the period 1997-2019. Consequently, based on descriptive analysis of annual GDP growth rate in the mentioned period, Poland had a very high average growth rate with low standard deviation. Significant level of GDP growth and low volatility of annual growth rates in Poland and Visegrad group, suggest that there is trend of substantial real growth connected with the high volume of received total and greenfield FDI inflows. Also, correlation analysis gives evidence of a strong and moderately high positive link between the FDI inflows and GDP growth in analysed sample of countries. However, in order to provide more specific conclusions concerning the connection between the FDI, especially greenfield FDI inflows and GDP growth rates, authors plan to estimate mentioned relations in selected sample of EEEs with panel data approach.

National objectives of faster economic growth, lower unemployment and more balanced current account can be achieved with the greater level of investment, especially greenfield investments. Based on the cited literature, motivation of foreign investors is mainly oriented towards macroeconomic conditions, business environment, qualified labour and government incentives. Having in mind the presented evidence of a positive correlation between FDI and GDP growth and other empirical findings in the vast literature suggesting that significant FDI inflows, especially greenfield FDI inflows, have positive effects on economic development, authors recommendations are directed towards the Western Balkan countries which should implement adequate measures to attract greater greenfield FDI inflows as well as export oriented FDI inflows, in order to bust the level of economic development, employment and improve external position. Therefore, Western Balkan countries need to continue to improve the quality of public institutions and infrastructure, as well as to establish more favourable business environment and conduct nonfinancial measures of promotional activities, in order to raise attractiveness of national market for foreign investors. Besides government authorities, presented research can also be interesting to the new investors that consider markets of EEEs as a potential investment destination. 


\section{References}

Anghel, B. (2006). Foreign Direct Investment in Transition Countries: a Dynamic Analysis at Firm Level. PhD Thesis, Universidad Autónoma de Barcelona, Barcelona, Spain.

Azizov, A. (2007). Determinants of FDI in CIS Countries with Transition Economy. Master of Science Paper, Aarhus School of Business, Aarhus, Denmark.

Bayar, Y. (2017). Greenfield and Brownfield Investments and Economic Growth: Evidence from Central and Eastern European Union Countries. Naše Gospodarstvo/Our Economy, 63(3), 19-26.

Beker Pucar, E., \& Srdić, S. (2018). Vulnerability of Emerging Europe in External Adjustment and Financing Mechanisms. Revue d'études comparatives EstOuest, 49(3), 93-121.

Blomstrom, M., \& Kokko, A. (1997). The Impact of Foreign Investment on Host Countries: A Review of the Empirical Evidence. World Bank Policy Research Working Paper No. 1745, 1-42.

Borensztein, E., De Gregorio, J., \& Lee, J.W. (1998). How does Foreign Direct Investment Affect Economic Growth? Journal of International Economics, Elsevier, 45, 115-135.

Brakman, S., Garretsen, H., \& Van Marrewijk, C. (2006). Cross-Border Mergers\&Acquisitions: The Facts as a Guide for International Economics. CES Info Working Papers No. 1823, 1-32.

Brooks, D.H., \& Sumulong, L.R. (2003). Foreign Direct Investment: The Role of Policy. ERD Policy Brief of Asian Development Bank, No. 23.

Canton, E., \& Solera, I. (2016). Greenfield Foreign Direct Investment and Structural Reforms in Europe: What Factors Determine Investments? European Commission, European Economy Discussion Paper 033, 1-29.

Caves, R.E. (1974). Causes of Direct Investment: Foreign Firms Shares in Canadian and United Kingdom Manufacturing Industries. The Review of Economics and Statistics, MIT Press, 56(3), 279-293.

Crespo, N., \& Fontoura, M.P. (2007). Determinant Factors of FDI, Spillovers - What do we really know. World Development, 35(3), 410-425.

Cvetanović, S., Despotović, D. \& Milovanović, G. (2018). Foreign Direct Investments as a Source of Financing of Economic Development of Western Balkan Countries. Ekonomika, 64(4), 17-28.

Cvetanović, S., Nedić, V., \& Despotović, L. (2019). The Analysis of Business Conditions in Western Balkan Countries. Ekonomika, 65(3), 13-19.

Dabla-Norris, E., Honda, J., Lahreche, A., \& Verdier, G. (2010). FDI Flows to Low-Income Countries: Global Drivers and Growth Implications. IMF Working Paper No. 132, 1-38.

De Mello Jr, L.R. (1999). Foreign Direct Investment-led Growth: Evidence from Time Series and Panel Data. Oxford Economic Papers, Oxford University Press, 51(1), 133-151. 
Denisia, V. (2010). Foreign Direct Investment Theories: An Overview of the Main FDI Theories. European Journal of Interdisciplinary Studies, 2(2), 104-110.

Dogru, B. (2012). The Effect of Institutional Variables on FDI Inflows: Evidence from Upper-middle Income Countries. GJEBS, Global Journal of Economics and Business Studies, 1(1), 1-12.

Dunning, J.H. (1992). The Global Economy, Domestic Governance, Strategies and Transnational Corporations: Interactions and Policy Implications. Transnational Corporations, 1(3), 7-45.

Dunning, J.H. (1994). Re-evaluating the Benefits of Foreign Direct Investment. Transnational Corporations, 3(1), 23-51.

Dunning, J.H. (2003). Determinants of Foreign Direct Investment: GlobalizationInduced Changes and the Role of Policies. Annual World Bank Conference on Development Economics - Europe, Toward Pro-Poor Policies: Aid, Institutions and Globalization. World Bank and Oxford University Press, 279-290.

Durham, J.B. (2004). Absorptive Capacity and the Effects of Foreign Direct Investment and Equity Foreign Portfolio Investment on Economic Growth. European Economic Review, 48, 285-306.

Ercegovac, D., \& Živkov, D. (2018). Competitiveness of the Serbian Economy, FDI and Balance of Trade Deficit Problem. International Scientific Conference „Economic Development and Competitiveness of European Countries“, Novi Sad School of Business.

Ercegovac, D., Vlaović Begović, S., \& Jovin, S. (2019). The analysis of the key indicators of the Republic of Serbia banking sector. The Annals of the Faculty of Economics in Subotica, 55(41), 81-94.

Gerschewski, S. (2013). Do Local Firms Benefit from Foreign Direct Investment? An Analysis of Spillover Effects in Developing Countries. Asian Social Science, Canadian Center of Science and Education, 9(4), 67-76.

Ginevičius, R., \& Šimelyte, A. (2011). Government Incentives Directed Towards Foreign Direct Investment: A Case of Central and Eastern Europe. Journal of Business Economics and Management, 12(3), 435-450.

Harms, P., \& Meon, P.G. (2014). Good and Bad FDI: The Growth Effects of Greenfield Investment and Mergers and Acquisitions in Developing Countries. CEB Working Paper No. 14/021.

Iamsiraroj, S., \& Ulubasoglu, M.A. (2015). Foreign Direct Investment and Economic Growth: A Real Relationship or Wishful Thinking? Economic Modelling, 51, 200-213.

Iamsiraroj, S. (2016). The Foreign Direct Investment - Economic Growth Nexus. International Review of Economics and Finance, 42, 116-133.

Josifidis, K., Allegret, J., \& Beker Pucar, E. (2013). Adjustment Mechanisms and Exchange Rate Regimes in New 2004 EU Members during the Financial Crisis. Post-Communist Economies, 25(1), 1-15. 
Jovanović, M., Damnjanović, J., \& Mirović, V. (2016). Direktni podsticaji stranim investitorima u Srbiji - korist ili šteta. Naučni skup „Inovacije i preduzetništvo pokretači razvoja i zapošljavanja“, Banja Luka: Екоnomski fakultet, BIH, 49-58.

Kalaš, B., Mirović, V., \& Andrašić, J. (2020). Cointegration analysis of indirect taxes and economic growth in the Republic of Serbia. The Annals of the Faculty of Economics in Subotica, 56(44), 3-10.

Kinoshita, Y., \& Campos, N.F. (2002). The Location Determinants of Foreign Direct Investment in Transition Economies. University of Michigan William Davidson Institute and CERP, 1-28.

Kurtishi-Kastrati, S. (2013). The Effects of Foreign Direct Investments for Host Countrys Economy. European Journal of Interdisciplinary Studies, 5(1), 26-38.

Li, X., \& Liu, X. (2005). Foreign Direct Investment and Economic Growth: An Increasingly Endogenous Relationship. World Development, 33(3), 393-407.

Luu, H.N. (2016). Greenfield Investments, Cross-border M\&As and Economic Growth in Emerging Countries. Economics and Business Letters, 5(3), 87-94.

Neto, P., Brandao, A., \& Cerqueira, A. (2010). The Impact of FDI, Cross Border Mergers and Acquisitions and Greenfield Investments on Economic Growth. IUP Journal of Business Strategy, 7(4), 24-45.

Noorbakhsh, F., Paloni, A., \& Youssef, A. (2001). Human Capital and FDI Inflows to Developing Countries: New Empirical Evidence. World Development, 29(9), 1593-1610.

Pegkas, P. (2015). The Impact of FDI on Economic Growth in Eurozone Countries. Journal of Economic Asymmetries, 12, 124-132.

Romer, P. (1993). Idea Gaps and Object Gaps in Economic Development. Journal of Monetary Economics, 32(3), 543-573.

Ruane, M.C.M. (2008). Attracting Foreign Direct Investments: Challenges and Opportunities for Smaller Host Economies. Journal of International Business Research, 7(2), 65-77.

Shukurov, S., Maitah, M., \& Smutka, L. (2016). Determinants of Foreign Direct Investments in Transition Economies: Case of Commonwealth of Independent Countries. Acta Universitatis Agriculturae et Silviculturae Mendelianae Brunensis, 64(5), 1749-1761.

United Nations UNCTAD. (2002). World Investment Report 2002, Transnational Corporations and Export Competitiveness.

United Nations UNCTAD. (2020). World Investment Report 2020, International Production Beyond the Pandemic. https://unctad.org/topic/investment/ investment-statistics-and-trends

Walkenhorst, P. (2004). Economic Transition and the Sectoral Patterns of Foreign Direct Investment. Emerging Markets Finance and Trade, 40(2), 5-26.

Wang, M., \& Wong, M.C.S. (2009). What Drives Economic Growth? The Case of Cross Border M\&A and Greenfield FDI Activities. Kyklos, 62(2), 316-330. 
Wells, L.T.J., \& Wint, A.G. (2000). Marketing a Country: Promotion as a Tool for Attraction Foreign Investment. Foreign Investment Advisory Service, Occasional Paper, 13.

World Bank - The World Development Indicators database:

https://datacatalog.worldbank.org/dataset/sustainable-development-goals

Żuk, P., Polgar, E.K., Savelin, L., Diaz del Hoyo, J.L., \& Konig, P. (2018). Real Convergence in Central, Eastern and South-eastern Europe. ECB Economic Bulletin, 3, 36-65. 